\title{
IANDUMOEMA UAI, A NEW GENUS AND SPECIES OF TROGLOBITIC HARVESTMAN FROM BRAZIL (ARACHNIDA, OPILIONES, GONYLEPTIDAE)
}

\author{
Ricardo Pinto-da-Rocha ${ }^{1}$
}

\begin{abstract}
A new genus and species of harvestman, Iandumoema uai, is described based on material from Gruta Olhos d'Água, Minas Gerais State, Brazil. Its troglomorphisms include depigmentation on body, legs and eyes. It is the third troglobitic species of harvestman recorded from Brazilian caves and the second in the family Gonyleptidae.

KEY WORDS. Arachnida, Opiliones, Gonyleptidae, troglobite, cave fauna
\end{abstract}

The Brazilian cave fauna was recently reviewed by PINTO-DA-ROCHA (1995), which presented a synopsis of the known fauna. It is noteworthy that São Paulo and Paraná States caves are better known, and in other regions only few surveys included caves. The Bambuí Speleological Province, which includes limestone caves from of Minas Gerais, Goiás and Bahia States, has been its cave fauna surveyed by CHAIMOWICZ (1986), TrajanO \& GNASPINI (1991), TRAJANO (1992) and GNASPINI \& TRAJANO (1994).

The troglobites present a strict relationship with the cave habitat, living only in this environment and frequently showing troglomorphisms (e.g. elongation of appendages, reduction or lack of eyes and pigmentation). Because of that, they use to have restricted distributions, generally defined by the lenght of the rock lenses in which the caves are developed. Consequently, the troglobites are potentially very endangered species.

Only two troglobitic species of harvestmen were recorded from Brazilian caves: Pachylospeleus strinatii Šilhavý, 1974 (Gonyleptidae, Pachylospeleinae) from Gruta das Areias de Cima, Gruta das Areias de Baixo e Ressurgência das Águas Quentes (three caves in the same rock lense and river system), in São Paulo State and Spaeleoleptes spaeleus Soares, 1966 (Minuidae) from Lapa Nova de Maquiné, Minas Gerais State (PINTO-DA-RocHA 1995).

All measurements in millimiters. Material is deposited in the Museu de Zoologia da Universidade de São Paulo (MZSP) and Museu Nacional, Universidade Federal do Rio de Janeiro (MNRJ).

1) Museu de Zoologia, Universidade de São Paulo. Caixa Postal $7172,01064-970$ São Paulo; São Paulo, Brasil. 


\section{landumoema gen.n.}

Etymology. From Tupi (Brazilian Indian language): Iandú = spider, $m o e m a$ $=$ false, in reference to the popular belief that harvestmen are spiders.

Description. Body outline piriform. Eye mound with long spine, placed in the middle of cephalothorax. Dorsal scute areas, posterior margin, free tergites and anal operculum unarmed. Area I divided by a median groove. Pedipalpal femur armed with a subapical seta. Tarsi I-II with more than six segments, III-IV with six segments. Penis: stylus short and thick, ventral process short and fan-like.

Diagnosis. According to the Roewerian system the new genus seems to be related to the following genera by armature of eye mound and unarmed body: Gyndulus Roewer, 1929; Heteropachyloidellus Mello-Leitão, 1927; Platygyndes Roewer, 1943; Progyndes Roewer, 1916; Pseudoacrographinotus Soares 1966 and Pucrolia Sørensen, 1895 (see SOARES \& SOARES 1954 and SOARES 1966a). Iandumoema differs from those by tarsal segmentation and presence of subapical seta in the pedipalpal femur (Fig. 3). Unfortunately, it is not possible to suggest the phylogenetical affinities at this moment because a few species of the Pachylinae had drawings of penis published and the unarmed scutal areas and free tergites are symplesiomorphies (except by the area III, which is armed with two spines in the primitive state). Besides, no hypothesis of internal phylogenetic relationships has been proposed to this subfamily.

\section{landumoema uai sp.n.}

Figs $1-9$

Pachylospeleinae new genus; Chaimowicz, 1986: 72-74.

Pachylinae: Pinto-da-Rocha, 1995: 82.

Holotype male (MZSP-15029), male and female paratypes (MZSP-15030): Brazil, Minas Gerais, Itacarambi County, Gruta Olhos d'Água $\left(15^{\circ} 06^{\prime} 47^{\prime \prime} \mathrm{S}\right.$ $\left.44^{\circ} 10^{\prime} 11^{\prime \prime} \mathrm{W}\right), 10$.VII.1993, E. Trajano leg.. Male and 2 females paratypes (MZSP15152), same data as holotype, 15.VI.1995, C. Galán leg.. Male and two females paratypes (MNRJ), same data as holotype, VII.1994.

Etymology. From Portuguese uai $=$ interjection much used by the people that live in Minas Gerais State that means surprise, horror or fear.

Description. Holotype (Figs 1-4, 6, 8-9). Measurements. Dorsal scute length, 4.04; cephalothorax length, 1.52; abdomen width, 3.16; cephalothorax width, 1.88. See table I for appendage measurements.

Table I. landumoema uai, appendage measurements (in milimeters): male holotype and female paratype (parenthesized).

\begin{tabular}{lccccccc}
\hline & Trochanter & Femur & Patella & Tibia & Metatarsus & Tarsus & Total \\
\hline Pedipalpus & $0.54(0.60)$ & $1.96(2.15)$ & $1.10(1.03)$ & $1.40(1.43)$ & $-(-)$ & $1.10(1.10)$ & $6.10(6.31)$ \\
Leg I & $0.46(0.55)$ & $4.40(4.24)$ & $1.12(1.16)$ & $3.37(3.24$ & $5.69(5.31)$ & $2.75(2.62)$ & $17.79(17.12)$ \\
Leg II & $0.60(0.65)$ & $8.64(8.32)$ & $1.44(1.52)$ & $7.37(7.44)$ & $8.88(8.50)$ & $9.84(9.62)$ & $36.77(36.05)$ \\
Leg III & $0.62(0.74)$ & $5.70(5.69)$ & $1.28(1.31)$ & $3.56(3.44)$ & $6.31(5.88)$ & $2.87(2.81)$ & $20.34(19.87)$ \\
Leg IV & $1.15(0.76)$ & $8.10(7.76)$ & $1.69(1.45)$ & $5.56(5.15)$ & $8.56(8.48)$ & $3.59(3.65)$ & $28.65(28.01)$ \\
\hline
\end{tabular}




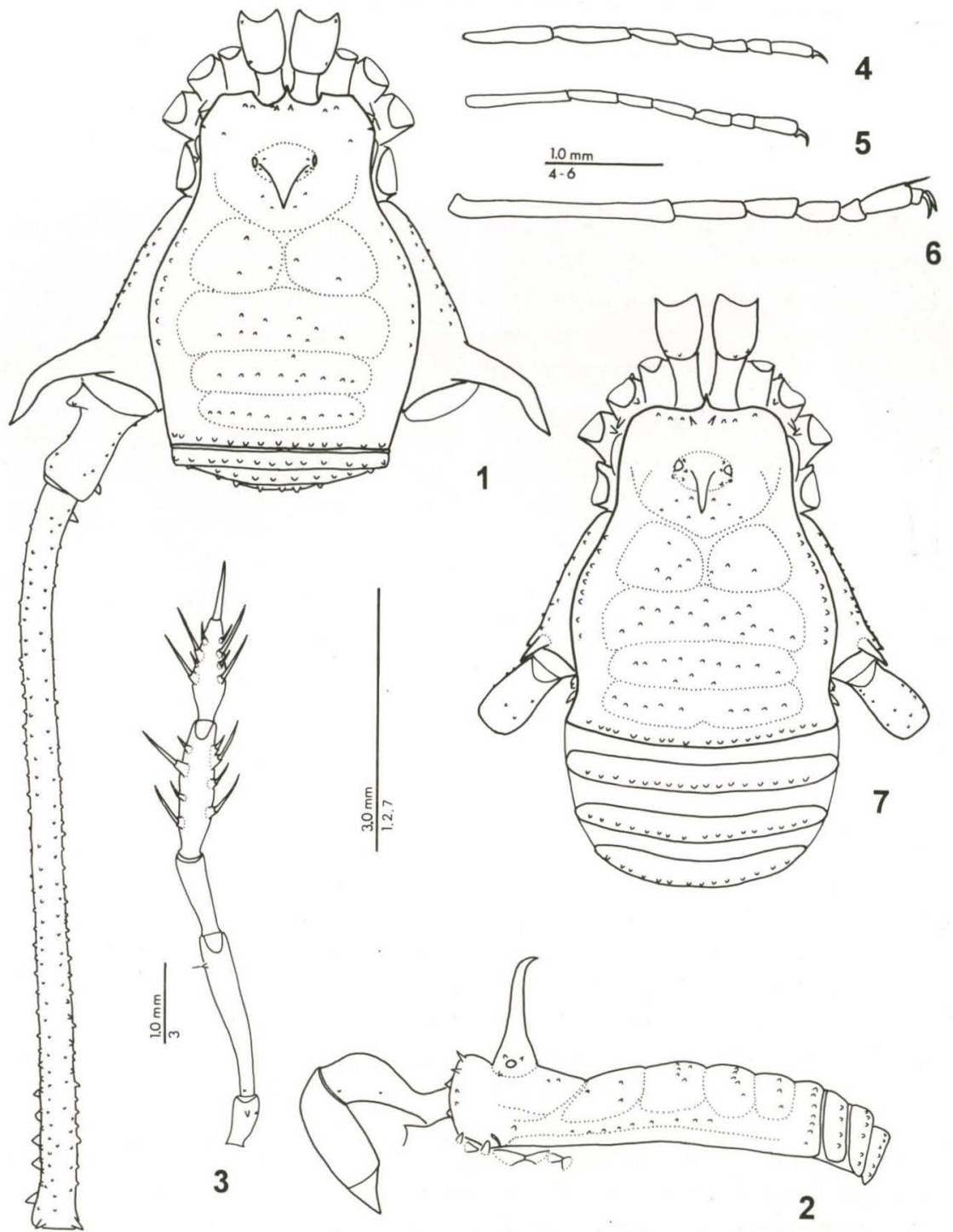

Figs. 1-7. landumoema uai. (1) Habitus, male holotype; (2) lateral, male; (3) ventral view of left pedipalpus, male; (4) tarsus I, male; (5) female paratype, MZSP; (6) tarsus IV, male; (7) habitus, female.

Dorsal scute (Figs 1-2). Body wider at area II. Anterior margin of cephalothorax with two tubercles each side, three median (longer). Scent gland openning visible dorsally, second opening visible lateraly. Eye mound with long spine, upwards, with acute apex pointing backwards; 3-4 tubercles near each eye. Cepha- 
lothorax with one tubercle each side, four behind eye mound. Lateral margin with eight tubercles placed near grooves I-II. Area I divided by a median groove, 2-3 tubercles each side; II-IV with 10, forming transverse row. Posterior margin with 14 tubercles. Free tergite I with 13 tubercles; II with 12; III with 11. Anal operculum with 14 tubercles.
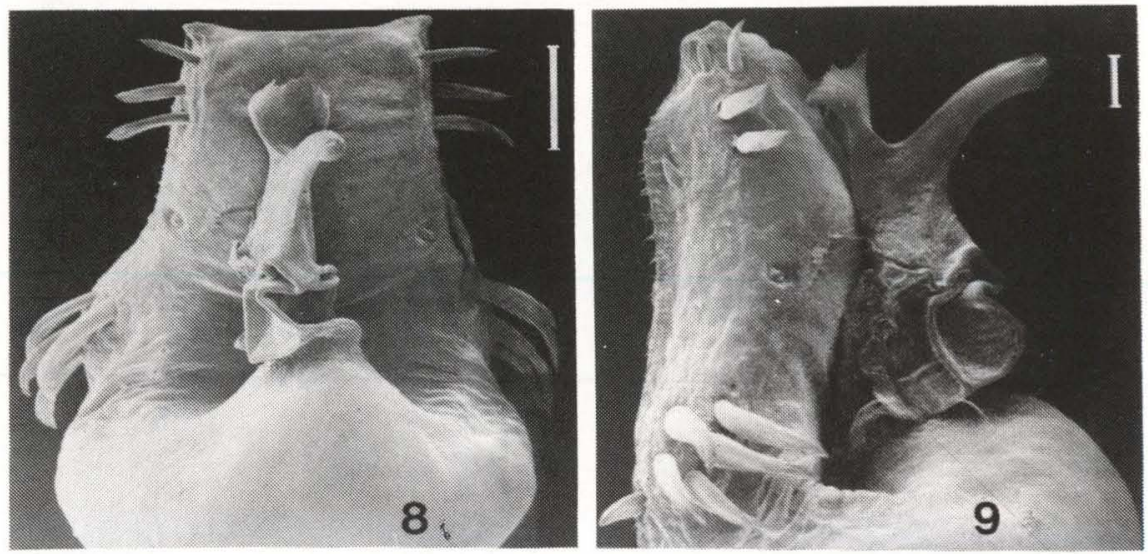

Figs. 8-9. landumoema uai, penis. (8) Dorsal; (9) lateral. Scale bars: figures $8=50 \mu \mathrm{m}$ and $9=$ $20 \mu \mathrm{m}$.

Venter. Coxa I with one anterior tubercle, one median row of 5, 5-7 posterior, five apical; II with four median tubercles, five to six posterior, five apical; III-IV irregularly tuberculate. Posterior margin and free sternites with one row of small tubercles. Anal operculum with two transverse rows of 12 and 14 tubercles.

Chelicera. Segment I elongate, two small dorsal tubercles; fixed finger (II) with five and movable finger with three tubercles.

Pedipalpus (Fig. 3). Coxa with 1 ventral tubercle. Trochanter with two ventral tubercles. Femur with four to five ventral, one subapical mesal tubercles. Patella smooth. Tibia-tarsus ectal and mesal setae Iili.

Legs. I-IV tuberculate. Coxa I with one anterior tubercle, one posterior towards coxa II; II with one anterior long, one posterior fused with one of III; III with one fused with one of IV; IV tuberculate laterally, with apical external apophysis long and curved at $1 / 3$ distal. Trochanter I with two retrolateral tubercles, one prolateral, two ventral; II with two retrolateral, five ventral; III with four retrolateral, two prolateral, seven ventral; IV elongate, with six retrolateral (apical longer), three prolateral (basal wide and long), nine ventral. Femora I-III straight, IV curved laterally and dorsally at $1 / 3$ from base, with two dorsal rows of tubercles (apical longer), one retrolateral, one prolateral, two ventral (tubercles longer at 1/3 apical). Tibia with one retrolateral row of tubercles (longer than others), one prolateral, two ventral. Tarsal segmentation: 7(3), 18(3), 6, 6. Basitarsus I sligthly swollen (Fig. 4). Tarsus IV as in figure 6. 
Penis (Figs 8-9). Ventral plate piriform attenuate, with three apical and six basal pairs of long setae, two apical and one intermediary pairs of short setae. Stylus short and thick, ventral process fan-like.

Coloration. Depigmented, uniformely yellowish. Black pigments of the eyes reduced. Lateral margin, apophysis IV and trochanter-femur IV reddishbrown.

Female paratype (Figs 5, 7). Measurements. Dorsal scute length, 3.64; cephalothorax length, 1.48; abdominal width, 2.64; cephalothorax width, 1.88. See table I for appendage measurements. As male except follows. Anterior margin of dorsal scute with two median tubercles and three each side (smaller than median). Area I with 3-5 tubercles; II with 16; III with 12; IV with nine. Lateral margin with 9-10. Chelicera: fixed finger with five tubercles; movable with four. Apophysis of coxa IV short, slightly curved downwards. Trochanter IV lacking the wide dorsobasal tubercle. Tubercles of femur-tibia IV similar in size. Tarsal segmentation: 7(3), 16-18(3), 6, 6. Basitarsus I not swollen.

Distribution. Known only from the type locality.

Biological notes. The Gruta Olhos d'Água, the largest cave in Minas Gerais, has $6,300 \mathrm{~m}$ of development. A small stream runs throughout $5,050 \mathrm{~m}$ of the cave, towards the main entrace, which is situated $2 \mathrm{~km}$ of the São Francisco river (Chaimowicz 1986). Iandumoema uai is known only from this cave so far. Eleonora Trajano, which studied the troglobitic catfish Trichomycterus sp. in the cave, made some biological observations of this species from March 1994 to May 1995. This opilionid was found throughout the cave, except for the first 50-100 m of the entrance, mainly on the ceiling of the stream gallery. Aggregations were not observed. The density, estimated visually, seems to be very low. An interesting aspect is that the inundation goes from October to March. The floodings are very common and happens suddenly, resulting in a fluctuation of the population. In fact, by the end of March 1994, several opilionids were observed in the stream gallery; some days later, a flooding occurred and they were carried away by the stream and probably died.

Iandumoema uai seems to show a preference for the area near the stream, probably due to the food sources available and diversity of substrate (CHAIMOWICZ 1986). This preference was also observed in the troglophilic Pachylinae Daguerreia inermis Soares \& Soares, 1947 in the Gruta da Lancinha (Paraná, Brazil), according to PINTO-DA-Rocha (1996b). Another gonyleptid troglobitic (Pachylospeleinae), Pachylospeleus strinatii Šilhavý, 1974, shows a preference for one place near the stream (higher density at Córrego Seco), in the Gruta das Areias de Cima(São Paulo, Brazil) and it is rare in other parts of the cave (PINTO-DA-ROCHA 1996a).

Iandumoema uai shows depigmented body, eyes and pedipalpal. The legs are sligthly slender and elongated. These characteristics are troglomorphisms shared with other troglobitic harvestmen (see GoodnigHT \& GoodNIGHT 1960; PINTODA-ROCHA 1996a). This new species is the third Brazilian troglobitic harvestman and the second known of the family Gonyleptidae (GNASPINI \& TRAJANO 1994; PINTO-DA-ROCHA 1995).

Spaeleoleptes spaeleus Soares, 1966b, like I. uai, shows depigmentation of body, appendages and eyes (SOARES 1966b) and Pachylospeleus strinatii shows 
depigmentation of body and appendages and large number of articles on distitarsi II (PINTO-DA-RochA 1996a).

The possible predators of $I$. uai are charontid amblipygids, which occur throughout the cave. Other potential predators, namely the spiders Ctenidae and Loxosceles sp. (Sicariidae) were observed only near the entrance, where I. uai does not occur (CHAIMOWICZ 1986).

Another harvestman, a probably trogloxene, Eusarcus aduncus (Mello-Leitão, 1942), was recorded in the entrance of the same cave (CHAIMOWICZ 1986).

ACKNOWLEDGMENTS. To E. Trajano (IBUSP) for sending the specimens and notes on the biology of $I$. uai. To P. Gnaspini (IBUSP), Adriano Kury (MNRJ) and Sônia Casari (MZSP) for the comments on the manuscript. To Dr. Alberto Ribeiro and Márcio V. Cruz for the facilities on Laboratório de Microscopia Eletrônica da Universidade de São Paulo. Grant from FAPESP (\#91/4054-7; 94/1307-0).

\section{REFERENCES}

Chaimowicz, F. 1986. Observações preliminares sobre o ecossistema da gruta Olhos d'Água, Itacarambi, MG. Espeleo-Tema 15: 65-77.

GNASPINI, P. \& E. TRAJANO. 1994. Brazilian cave invertebrates, with a checklist of troglomorphic taxa. Revta bras. Ent. 38 (4): 549-584.

GoodNIGHT, C.L. \& M.L. GooDNIGHT. 1960. Speciation among cave opilionids of the United States. Am. Midl. Natur. 64 (1): 34-38.

PinTO-DA-RochA, R. 1995. Sinopse da fauna cavernícola do Brasil (1907-1994). Papéis avulsos Dept. Zool., São Paulo, 39 (6): 61-173.

Šithavy, 1974 in the Gretes and population size of Pachylospelens strinati Šilhavý, 1974 in the Gruta das Areias de Cima, Iporanga, southeastern Brazil (Arachnida; Opiliones, Gonyleptidae). Bull. British Arachn. Soc. 10 (5): 189-192.

-1996b. Description of the male of Daguerreia inermis Soares \& Soares, 1947, with biological notes on the population size in the Gruta da Lancinha, Paraná, Brazil (Arachnida: Opiliones, Gonyleptidae). Revta bras. Zool. 13 (4): 833-842.

SoARes, B.A.M. \& H.E.M. SoARES. 1954. Monografia dos gêneros de opiliões neotrópicos. Arq. Zool., São Paulo, 8 (9): 225-302.

SOARES, H.E.M. 1966a. Opiliões da "Coleção Gofferjé" (Opiliones: Gonyleptidae, Phalangodidae). Papéis avulsos Dept. Zool., São Paulo, 18 (10): 87-102. 1966b. Novos opiliões da coleção "Otto Schubart" (Opiliones: Cosmetidae, Gonyleptidae, Phalangodidae). Papéis avulsos Dept. Zool., São Paulo, 18 (11): 103-115.

Trajano, E. 1992. Nota sobre os cavernícolas da Província Espeleológica do Bambuí. Espeleo-Tema 16: 103-108.

TRAJANO, E. \& P. GNASPINI. 1991. Fauna cavernícola brasileira, com uma análise preliminar da distribuição dos táxons. Revta bras. Zool. 7 (3): 383-407.

Recebido em 14.III.1996; aceito em 02.XII.1996. 